\title{
Pattern and Potential Causes of White-faced Ibis, Plegadis chihi, Establishment in the Northern Prairie and Parkland Region of North America
}

\author{
Jill A. Shaffer ${ }^{1}$, Gregory A. KnUtSen ${ }^{2}$, Ron E. Martin ${ }^{3}$, and Joel S. Brice ${ }^{4}$ \\ ${ }^{1}$ U.S. Geological Survey, Northern Prairie Wildlife Research Center, $871137^{\text {th }}$ Street SE, Jamestown, North Dakota 58401 \\ USA; e-mail: jshaffer@usgs.gov \\ ${ }^{2}$ U.S. Fish and Wildlife Service, Long Lake National Wildlife Refuge Complex, $12000353^{\text {rd }}$ Street SE, Moffit, North Dakota \\ 58560 USA \\ ${ }^{3} 16900125^{\text {th }}$ Street SE, Sawyer, North Dakota 58781 USA \\ ${ }^{4}$ Delta Waterfowl Foundation, 1305 East Central Avenue, Bismarck, North Dakota 58501 USA
}

Shaffer, Jill A., Gregory A. Knutsen, Ron E. Martin, and Joel S. Brice. 2007. Pattern and potential causes of White-faced Ibis, Plegadis chihi, establishment in the northern prairie and parkland region of North America. Canadian FieldNaturalist 121(1): 46-57.

The Northern Prairie and Parkland Waterbird Conservation Plan calls for renewed attention to determining the current status of waterbird populations, their distributions, and conservation needs. It highlights the need for baseline information on the White-faced Ibis (Plegadis chihi). In response, we examined the historical and current distribution of the ibis in North Dakota and summarized first sightings and nest records for the provinces and other states composing the northern prairie and parkland region. The establishment of breeding colonies of White-faced Ibis here may be due to climate and precipitation patterns, invasion and spread of Narrowleaf Cattail (Typha angustifolia), changes in agricultural practices, habitat loss and range expansion in the southern and western portions of the species' range, and increases in ibis populations in the Intermountain West. We placed special emphasis on North Dakota, a state for which there is scant published information concerning the current status of this species. In recent decades, the ibis has become a regular breeding-season resident in North Dakota and in other areas of the northern prairie and parkland region. From 1882 to 2002, there were 145 reports of one or more Whitefaced Ibis in North Dakota, including 93 reports during the breeding season (15 May to 31 August), 49 during the nonbreeding season (1 September to 14 May), and three for which the season of occurrence was not reported. Prior to the 1960s, there were only three records of the species in North Dakota. Observations of White-faced Ibises in North Dakota increased dramatically between the 1960s and the early 21st century, and the species has been observed nearly annually since 1971 . The first White-faced Ibis nesting activity in the state was recorded in 1978, and to date, there have been 21 known records of nesting activity in the state. The species nested in large (>300 ha) semipermanent or permanent wetlands within mixedspecies colonies ranging in areal extent from small $(0.1 \mathrm{ha})$ to fairly large $(27 \mathrm{ha})$, and colonies were located in patches of emergent vegetation dominated by cattails (Typha) and bulrushes (Scirpus). We classify the White-faced Ibis as a fairly common migrant and a locally uncommon breeder east of the Missouri River and a casual migrant west of the Missouri River.

Key Words: White-faced Ibis, Plegadis chihi, colonial-nesting waterbird, distribution, status, northern prairie and parkland region, North Dakota.

The White-faced Ibis (Plegadis chihi; hereafter ibis) is a wading bird that nests in wetlands with emergent vegetation and forages in shallow wetlands, flooded hay meadows, or agricultural fields (Ryder and Manry 1994). Northernmost populations undertake regular north-south migrations, whereas populations in Texas and Louisiana are mainly year-round residents (Ryder and Manry 1994). Extralimital wanderings seem to be more prevalent before the nesting season than afterward and may represent individuals seeking new nesting areas when traditional sites are dry or have been destroyed by humans (Ryder 1967; Ryder and Manry 1994). During the twentieth century, numerous sightings of the species east and north of its historical range were reported (Sabo 1992; Jorgenson and Dinsmore 2005).

The recently completed North American Waterbird Conservation Plan (Kushlan et al. 2002) and its regional offshoot, the Northern Prairie and Parkland Waterbird Conservation Plan (NPPWCP) (Beyersbergen et al.
2004), called for renewed attention to determining the current status of waterbird populations, their distributions, and conservation needs. The NPPWCP emphasized that information on the breeding distribution of ibis in the northern prairie and parkland region (portions of Alberta, Saskatchewan, Manitoba, Montana, North Dakota, South Dakota, Minnesota, Iowa, and Nebraska) is needed to serve as a baseline for future monitoring needs (Beyersbergen et al. 2004). In response to these information needs, we examined the historical and current distribution of the ibis in North Dakota and summarized first sightings and nesting records for the provinces and states composing the northern prairie and parkland region. We placed special emphasis on North Dakota, a state for which there is scant published information concerning the current status of this species.

Lokemoen (1979) and Schmidt (1980a) summarized the first occurrences and nest records of White-faced 
Ibis in North Dakota. Sabo (1992) described the status, range, first occurrences, and first nesting observations for some Great Plains states and Canadian provinces. Goossen et al. (1995) provided a detailed list of observations and breeding records for the species throughout Canada. Jorgenson and Dinsmore (2005) provided an update of breeding records throughout the Great Plains. In this paper, we summarize the reported occurrences of White-faced Ibis in North Dakota up to 2002, and we report nest records through 2003, beyond which time the U.S. Fish and Wildlife Service (USFWS) no longer quantified colony and nest numbers. We discuss factors influencing the species' expansion into the state and provide data on the species' breeding habitat. We also explain how the pattern of occurrence of the species in North Dakota compares to the general pattern throughout the rest of the northern prairie and parkland region.

\section{Methods}

Records of ibis occurrences in North Dakota were summarized from published reports, including those in American Birds, Audubon Field Notes, National Audubon Society Field Notes, and North American Birds, and unpublished reports filed with the North Dakota Birding Society (REM, unpublished data). We included data from the North American Breeding Bird Survey (BBS; 1966-2002; Sauer et al. 2005*), the National Audubon Society's Christmas Bird Count (NAS 2007*), and banding records from the U.S. Geological Survey Bird Banding Laboratory (USGS 2007*).

We defined a record as a museum specimen or a reported occurrence of an individual, group of individuals, or a colony. Records were summarized by date (year, month, and day if known) and location (to county level at a minimum). Nest records were defined as the presence of nests, eggs, dependent young, or adults exhibiting breeding behavior (e.g., carrying nesting material). Observations from 15 May to 31 August were considered breeding-season records, and observations from 1 September to 14 May were considered nonbreeding-season records, based on authors' observations of ibis behavior and phenological information as described by Ryder and Manry (1994). Occurrences of ibises at the same location over a range of days to months were counted as a single observation for purposes of annual summaries. To summarize data for the breeding and nonbreeding seasons, reports of the species at the same location within both seasons were counted as separate records, unless information indicated that individuals had nested at the location and were still present during the nonbreeding season.

We summarized information on use of wetlands for nesting from one published nest record and from three studies that measured habitat attributes of nesting ibis in North Dakota. Schmidt (1980a) provided a brief description of the habitat attributes of a wetland that supported several flightless young in 1978 and of one nest in southern North Dakota in 1979. During June and July 2000, Brice (2003) documented a multi-species colony that included ibis nests at Lake Alice National Wildlife Refuge (NWR; 48¹9'54"N, 9906'38"W), western Ramsey County, in northeastern North Dakota. Colony size was defined as the area occupied by nests of all colonially nesting species within the colony boundary, not just by ibis nests. Within the colony boundary, number of ibis nests, dominant vegetation, and presence of other bird species nesting within the colony were recorded. Two transects were placed lengthwise through the colony. The percent of water surface that was not covered or obstructed by standing or horizontal residual vegetation (i.e., percent open water), residual stem density, and water depth were measured within $861-\mathrm{m}^{2}$ sampling frames placed at 10-m intervals along the two transects (Table 1). Percent open water within the colony was recorded by visual estimation. Water depth was recorded using an approximately $3-\mathrm{cm}$ diameter closet rod marked in 1-dm intervals. In 2001, this same colony was monitored for the presence of breeding ibises by USFWS personnel (Phelps and Meeks 2001*). Percentages of colony area composed of residual emergent vegetation and open water were visually estimated. During June and July 2001 and 2002, the USFWS (2001*, 2002*) documented ibis nesting activity on USFWS lands in Burleigh, Emmons, and Kidder counties in south-central North Dakota. The number of nests, the number of colonies, the dominant vegetation within colonies, and the presence of other nesting bird species were recorded on one NWR and one waterfowl production area (WPA). The ratio of live-to-residual emergent vegetation within colonies was visually estimated. In 2001, water depth at nests was measured using a meter stick. During June 2003, Knutsen (2004*) conducted a colonial-nesting waterbird inventory on 183 wetlands located on NWRs and WPAs in the Long Lake Wetland Management District (Knutsen 2004*). Wetlands were divided into three strata (high, moderate, and low) related to their likelihood of supporting a waterbird colony, based on habitat conditions in 2003, as well as the size and permanence of the wetlands (sensu Stewart and Kantrud 1971). Number of nests, number of colonies, dominant vegetation, and the presence of other colonial bird species nesting within colonies were recorded. The ratio of live-to-residual emergent vegetation within colonies and the percent of the colony's area that was composed of residual emergent vegetation and open water were visually estimated. Water depth was not measured in 2003. Vegetation density was classified into one of three categories: dense (heavy, thick stands of emergent vegetation with few visible openings), moderate (contiguous stands of emergent vegetation with numerous small openings), or sparse (large "canoe-sized" openings within the emergent vegetation of open-water floating mat colonies). 


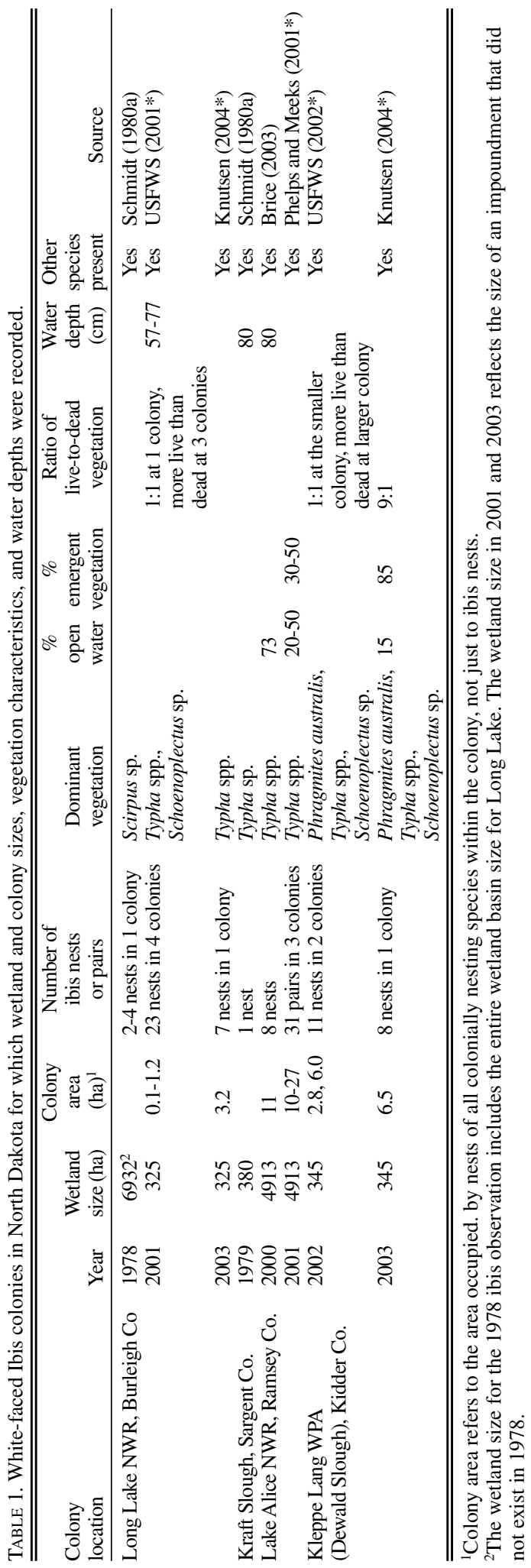

\section{Results}

Ibis in North Dakota

The only reported observation of ibis in North Dakota in the nineteenth century was of a specimen that was collected in 1882 and deposited in the University of Michigan's Museum of Zoology (Wood 1923). Wood (1923) also reported the first two occurrences in the twentieth century, including single individuals in Morton County in 1912 and in Slope County in May 1920. The fourth report of an ibis occurred over 40 years later, on 5 June 1961, in Stutsman County (fide REM). This observation marked the beginning of the species' documented range expansion into North Dakota (Figure 1). Observations of ibis increased markedly between the 1960s and 1990s. Between 1961 and 2002, the species has been observed nearly annually, occurring in all but nine of the 42 years.

From 1882 to 2002, there were 145 reports of one or more White-faced Ibis in North Dakota, including 93 reports during the breeding season, 49 during the nonbreeding season, and three for which the season of occurrence was not reported. Of the 107 occurrences of the species during the twentieth century, 71 occurred during the breeding season, 34 during the nonbreeding season, and the season of occurrence for two early records was unknown (Figure 1). During the twentieth century, no occurrences were reported from January through March, and two occurrences each were reported in November and December (Figure 2). The earliest observation within a year was 14 April, which occurred in 2002 at Long Lake NWR (4643'59"N, $100^{\circ} 05^{\prime} 43^{\prime \prime} \mathrm{W}$ ) in Burleigh County (P. C. Van Ningen, U.S. Fish and Wildlife Service, Moffit, North Dakota, personal communication). The latest observation within a year was 17 December 1999 in Sargent County (D. Kinzler, Oakes, North Dakota, personal communication). The largest group of birds observed during the breeding season was about 400 individuals on 11 August 2001 in Sargent County; this group was undoubtedly a post-breeding flock (Martin 2002). The largest group of birds observed during the nonbreeding season was over 50 individuals in September 2000 in Kidder County by H. F. Duebbert (Martin 2001).

From 1912 to 2002, ibises have been sighted in 28 $(53 \%)$ of the 53 counties in North Dakota (Figure 3). Observations first occurred west of the Missouri River. The two observations in the early part of the twentieth century both occurred in the western part of the state (Wood 1923). Of the eight occurrences in the 1960s, all were reported from southern counties, but only one occurred west of the Missouri River, in Slope County (G. B. Berkey, personal communication). Most observations after the 1960s were east and north of the Missouri River. The first occurrences in the northern half of the state occurred in 1973 at Upper Souris NWR (4830'11"N, 101³1'50"W), Renville County, by I. O. Rostad (Houston 1974) and in 1974 at J. Clark Salyer NWR (48 40'52"N, 10047'23"W), McHenry County, 


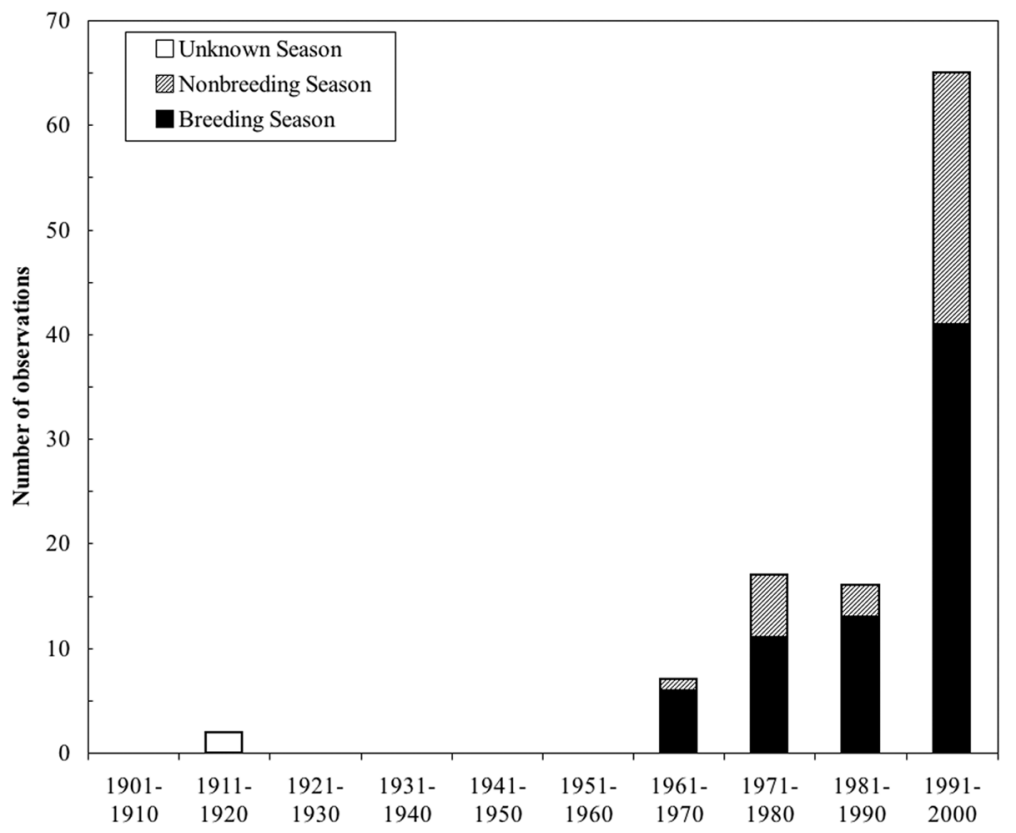

FIGURE 1. Records of White-faced Ibis occurrences in North Dakota during the twentieth century, by decade.

by R. C. Fields (Houston and Houston 1974). The first sightings in five counties (Bottineau, Foster, Mercer, Pierce, and Ward) occurred recently, within 2001-2002.

To date, there are 21 records of nesting activity in North Dakota (Table 2). The first nest was reported by R. A. Schmidt and R. N. Randall in 1978 (Serr 1978; Schmidt 1980a). From 1978 to 2003, nests have been reported in ten of the 26 years, with the majority occurring between 2000 and 2003. Nests or nesting activity have been reported in each of the four recent years from 2000 to 2003. The number of nests discovered within an individual wetland varied from one to 31 . All 21 nesting observations were recorded in June, July, or August. Observations in June indicated that nesting had been initiated in May. By August, young or fledglings were observed. Nesting ibises have been observed in eight of the 53 counties (Table 2, Figure 3). Most nesting activity was recorded in Burleigh and Kidder counties (Table 2). Of the ten known wetlands that have contained nesting ibises, six are federally owned; two involve a mixture of federal, state, and/or private ownerships; and two are privately owned.

The ibis has been recorded on a Breeding Bird Survey route in North Dakota in only one year since the survey's inception in 1966. On 10 June 1999, three individual ibis were reported by $\mathrm{H}$. C. Talkington (Mandan, North Dakota, personal communication) on his BBS route south of Tappen in Kidder County. According to banding records, three flightless young were banded in late July 1979, in western Sargent Coun- ty (K. Klimkiewicz, U.S. Geological Survey, Laurel, Maryland, personal communication). No ibises have been recorded in North Dakota on a Christmas Bird Count, which have been conducted in the state since the early 1900s.

In North Dakota, ibises have been found breeding only in large (>300 ha) semipermanent or permanent wetlands. Colonies, all of which were mixed-species colonies, were located in patches of emergent vegetation dominated by cattails and bulrushes and ranged in areal extent from 0.1 to 27 ha (Table 1). Ibises appeared to prefer a fairly equal proportion of open water and emergent vegetation within a wetland basin, with half or more of the vegetation composed of live rather than residual stems. Water depths varied from 60 to $80 \mathrm{~cm}$. Schmidt (1980a) reported that one ibis nest was built just above the water level in residual cattails interspersed with open water and was located $600 \mathrm{~m}$ from shore and $20 \mathrm{~m}$ from the central open water area of the wetland basin. Flightless ibises were located in emergent vegetation about $700 \mathrm{~m}$ from shore and $35 \mathrm{~m}$ from open water. Brice (2003) reported that the mean density of residual cattail stems within an ibis colony was 44 stems $/ \mathrm{m}^{2}$. Knutsen $\left(2004^{*}\right)$ found that two of 40 waterbird colonies contained ibis nests. Both of these ibis colonies were located on wetlands categorized as having a high probability of supporting a waterbird colony. One of the colonies was located on an impoundment of Long Lake that contained ibises in 2001, and the other was located on a WPA that contained 


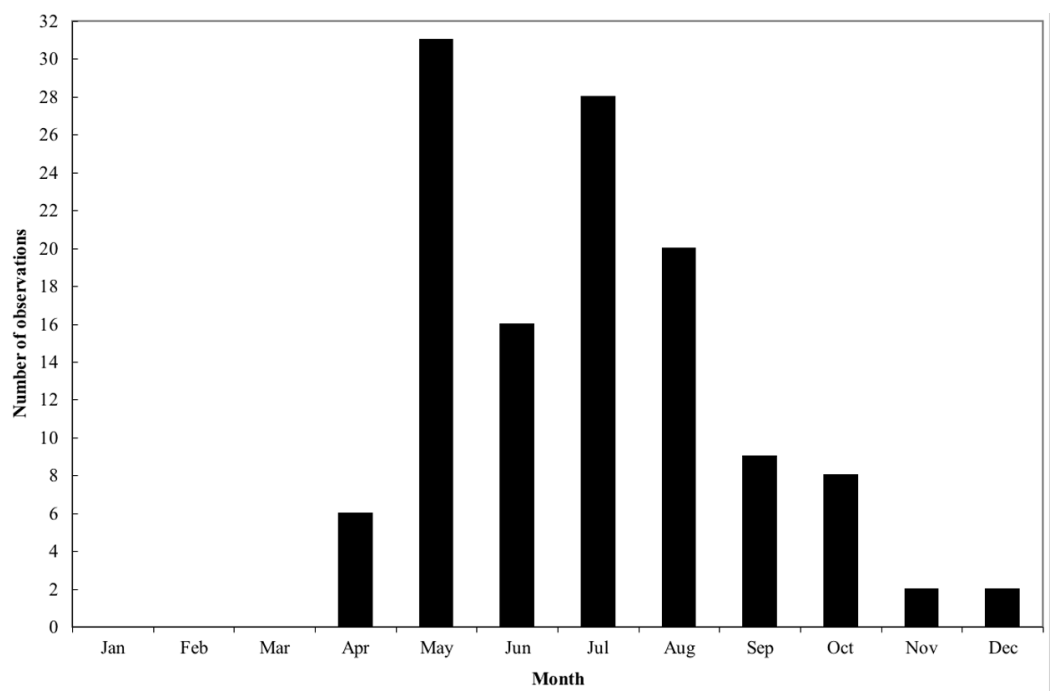

FIGURE 2. Records of White-faced Ibis occurrences in North Dakota during the twentieth century, by month. An observation was counted once, regardless of whether the observation was of one or of multiple individuals.

ibises in 2002 (Table 1). Vegetation density within the colony in the impoundment was categorized as moderate, whereas vegetation density within the colony in the WPA was categorized as dense. Several other waterbird species occurred at colonies with ibises (Table 1). These species included Ruddy Duck (Oxyura jamaicensis), Horned Grebe (Podiceps auritus), Eared Grebe (Podiceps nigricollis), Western Grebe (Aechmophorus occidentalis), Clark's Grebe (Aechmophorus clarkii), Snowy Egret (Egretta thula), Cattle Egret (Bubulcus ibis), Black-crowned Night-Heron (Nycticorax nycticorax), American Coot (Fulica americana), Franklin's Gull (Larus pipixcan), Forster's Tern (Sterna forsteri), and Black Tern (Chlidonias niger) (Schmidt 1980a; Phelps and Meeks 2001*; USFWS 2001*, 2002*; Brice 2003; Knutsen 2004*).

\section{Ibis expansion in the northern prairie and parkland region}

There appears to be a consistent pattern throughout the northern prairie and parkland region concerning the chronological progression from the first occurrences to the establishment of breeding colonies (Table 3). From our examination of regional patterns of ibis distribution, we determined that the species rarely visited the northern prairie and parkland region in the late nineteenth and early twentieth centuries and did not develop breeding populations until the late twentieth century. North Dakota, Iowa, and Minnesota reported ibis occurrences as early as the late nineteenth century (Peabody 1896; Lokemoen 1979; Schmidt 1980a; Janssen 1987; Kent and Dinsmore 1996), and Nebraska and Alberta reported occurrences during the early twentieth century (Kondla et al. 1973; Goossen et al. 1995; Mollhoff 2001). Montana, South Dakota, Manitoba, and Saskatchewan did not report ibis occurrences until the mid-to-late twentieth century (Skaar 1969; Serr 1975; DuBois 1989; Goossen et al. 1995; Tallman et al. 2002). The first nests in the region were reported in 1894 in Minnesota (Peabody 1896) and in 1916 in Nebraska (Mollhoff 2001), but other states and provinces did not report nesting ibis until the mid-to-late twentieth century. Two nest records have been reported for Saskatchewan, both of which occurred in 2000 (B. Hepworth, Ducks Unlimited Canada, Regina, Saskatchewan, personal communication; P. Taylor, Canadian Wildlife Service, Environment Canada, Saskatoon, Saskatchewan, personal communication). Bazin and Artuso (2006) documented the first nest record for Manitoba in 2005. Jorgenson and Dinsmore (2005) summarized recent nesting records for Alberta and some of the states in the northern prairie and parkland region. An additional nest record in Alberta was reported by Flockhart (2001).

\section{Discussion}

The number of occurrences of ibises in North Dakota reached the point that the North Dakota Birding Society stopped recording new nonbreeding observations after about 2002 (REM, unpublished data). Nesting ibises are becoming increasingly common, with multiple reports of nests every year from 2000 to 2003 (Table 2). Spring arrival in North Dakota typically begins in mid-to-late April, and birds begin departing in September (Figure 2). Few birds remain in the state in November and December, and no records exist for January through March. Nesting occurs from mid-May to late August (Table 2). The ibis appears to nest colonially with other waterbird species as has been report- 


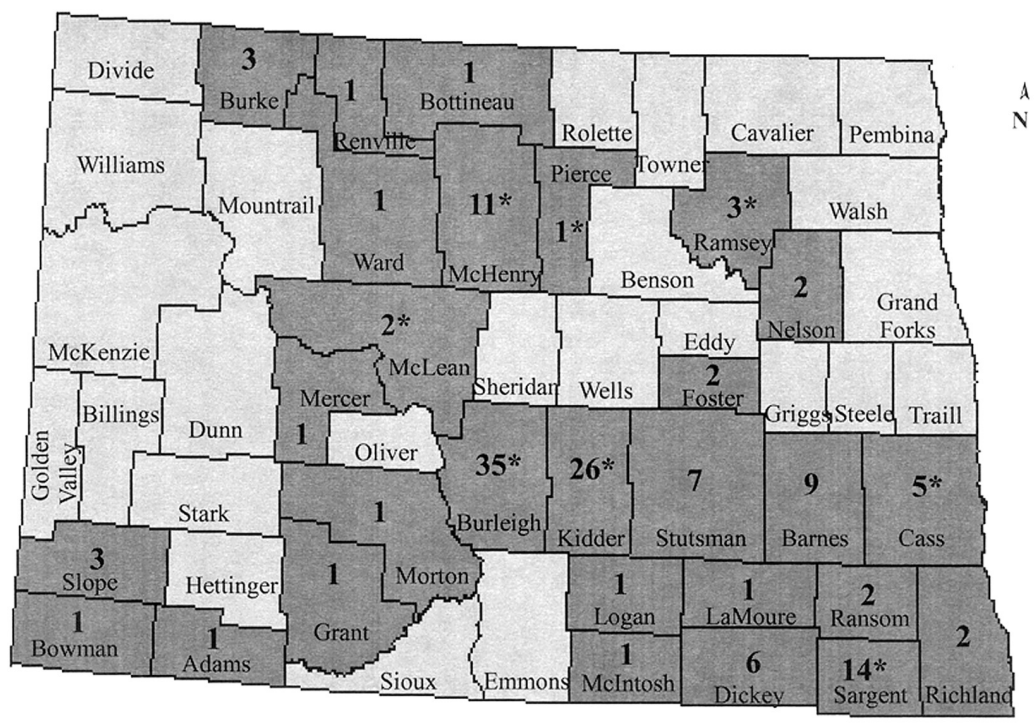

FIGURE 3. Records of White-faced Ibis occurrences in North Dakota during the twentieth century and 2001-2002, by county. Asterisks (*) denote counties in which nesting activity has been observed during the twentieth century and 2001-2003.

ed by other researchers in the northern prairie and parkland region (Peabody 1896; Dinsmore and Dinsmore 1986; Mollhoff 2001). Based on our findings, we believe that the status of ibis in North Dakota is that of a fairly common migrant and a locally uncommon breeder east of the Missouri River and a casual migrant west of the Missouri River.

Of the ten known wetlands that have contained nesting ibis, most are under federal management. These wetlands are protected from drainage and tillage; therefore, thick stands of cattails and other tall wetland vegetation are able to become established in some years (Table 1). These wetlands also may experience higher levels of human visitation than privately owned wetlands. More human visits, either by federal employees conducting biological surveys or by bird watchers and nature enthusiasts visiting the NWRs, WPAs, and other federal properties, could explain the greater number of reports of nesting activity on federally managed properties.

Because ibises were present as vagrants in some parts of the northern prairie and parkland region in the late nineteenth century, several authors have speculated that the presence of breeding colonies in the twentieth century was not so much an expansion of the species' range as it was the reclamation of portions of the species' former range (Ryder and Manry 1994; Dinsmore et al. 1984). Goossen et al. (1995) advanced several explanations for the expansion of breeding ibises into Canada, which included population growth; loss of habitat to draining, flooding, or drought in other portions of the species' breeding range; dispersal; and an increase in suitable habitat due to the advent of managed or re- stored wetlands and irrigation. The virtual absence of sightings from the late nineteenth century through the early twentieth century in the northern prairie and parkland region (Table 3 ) coincided with the withdrawal of ibises from inland areas in Texas, suggesting to Jorgenson and Dinsmore (2005) that sightings in northern regions in the late nineteenth century and first half of the twentieth century were linked to fluctuations in the Gulf Coast populations. They examined the historical status of the species from Alberta to Texas and suggested that the current range expansion appears to be unprecedented. They contended that the idea that ibises occupied the northern Great Plains in the nineteenth century was based on only three nesting records that occurred at a time when extralimital breeding of the species was being documented elsewhere in the continent. They suggested that the development of breeding populations of ibises was linked to population fluctuations in the species' core breeding areas of Texas, Louisiana, and, more likely in modern times, to fluctuations occurring in the Intermountain West, the region of North America lying between the Rocky Mountains to the east and the Cascades and Sierra Nevada to the west.

Drawing upon knowledge of habitat, climate, and socioeconomic conditions in the northern Great Plains, using North Dakota as an example, we suggest further explanations for the pattern of ibis observations. Those explanations include habitat perturbations and habitat loss in other parts of the ibis' range, climate and precipitation patterns in the northern prairie and parkland region that impacted habitat conditions, and socioeconomic conditions. We concur with Jorgenson 


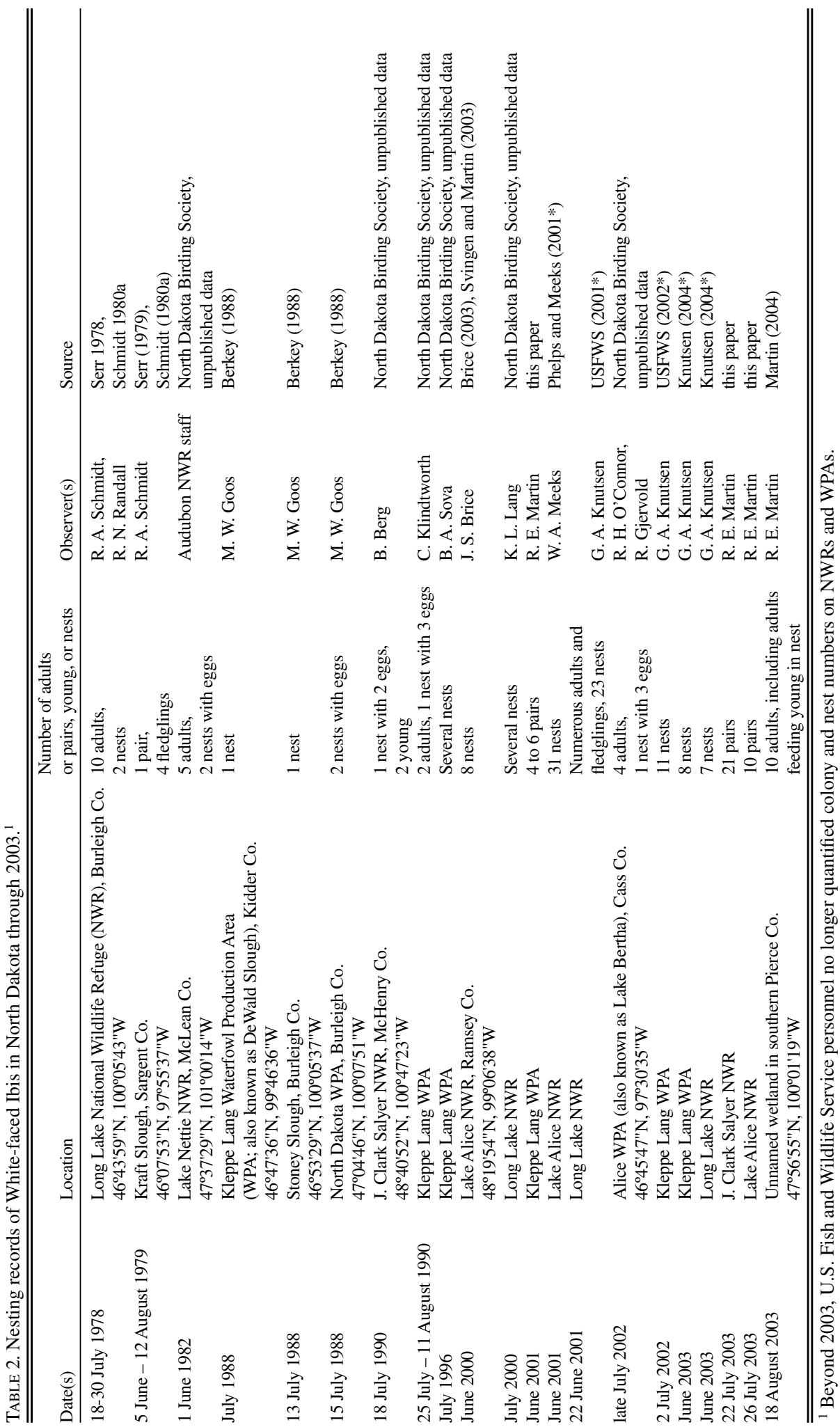


and Dinsmore's (2005) suggestion that ibis occurrences in the northern Great Plains during the late nineteenth century and early twentieth century may have been due to extralimital wandering as was occurring in other parts of the U.S. at the same time, combined with the species' predilection for post-breeding dispersal north of its nesting grounds (Ryder 1967; Ryder and Manry 1994).

No ibises were reported in North Dakota between 1920 and 1961 (Table 3). Plausible explanations include a scarcity of suitable nesting habitat and a low level of human engagement in nature-based activities. Potential suitable wetland habitat for ibises deteriorated with the onset of drought that characterized the 1930s, the Dust Bowl years (Robinson 1966). Given the duration and intensity of that drought, it is highly likely that suitable wetland habitat was largely nonexistent in the 1930s.

The widespread drought of the 1930s, combined with economic collapse during the Great Depression, resulted in a human exodus from North Dakota (Robinson 1966). The human population in North Dakota reached the highest levels to date, according to the 1930 census, and experienced a 9\% decline between 1930 and 1950 (USCB 2005), with much of the decline occurring in rural areas. The human population continues to fluctuate and recovered somewhat from the 1950s, but never has reached the levels experienced prior to the 1930s. During the 1940s, fewer people lived in North Dakota than in the 1920s or 1930s (Kazeck 1956), and some people that remained were called to war or were engaged in war-related activities. During the war, ammunition was rationed and hunting activities were subsequently curtailed. Overall, then, there likely were fewer people afield and thus there were fewer chances of people encountering ibises during this time.

Also during the 1940s, moisture conditions, and thus potential ibis habitat, began to improve, with the highest annual precipitation at Bismarck between 1900 and 2000 occurring in 1941 with $79.1 \mathrm{~cm}$ (NCDC 2004*). Concomitant with improved moisture conditions was the invasion into North Dakota of an introduced species of European cattail, the Narrowleaf Cattail (Typha angustifolia), which was first collected in North Dakota in 1942 at Long Lake NWR (Kantrud 1992). Prior to that time, there were few cattail-dominated wetlands in North Dakota, and the few stands that did exist were in boggy areas around freshwater lakes (Kantrud 1992). Narrowleaf Cattail was restricted largely to the southeastern portion of North Dakota in the early 1960s and spread to many wetlands in central North Dakota by the 1970s (Kantrud 1992). However, the invasive species hybridized with the native Broadleaf Cattail (Typha latifolia), and the resulting hybrid (Typha $\times$ glauca) spread rapidly throughout the prairie pothole region of North Dakota during the 1950s, becoming the most abundant large hydrophyte in the state (Kantrud 1992). Wetlands dominated by the hybrid cattail potentially provided prime breeding habitat for ibises. Also, despite the decrease in the number

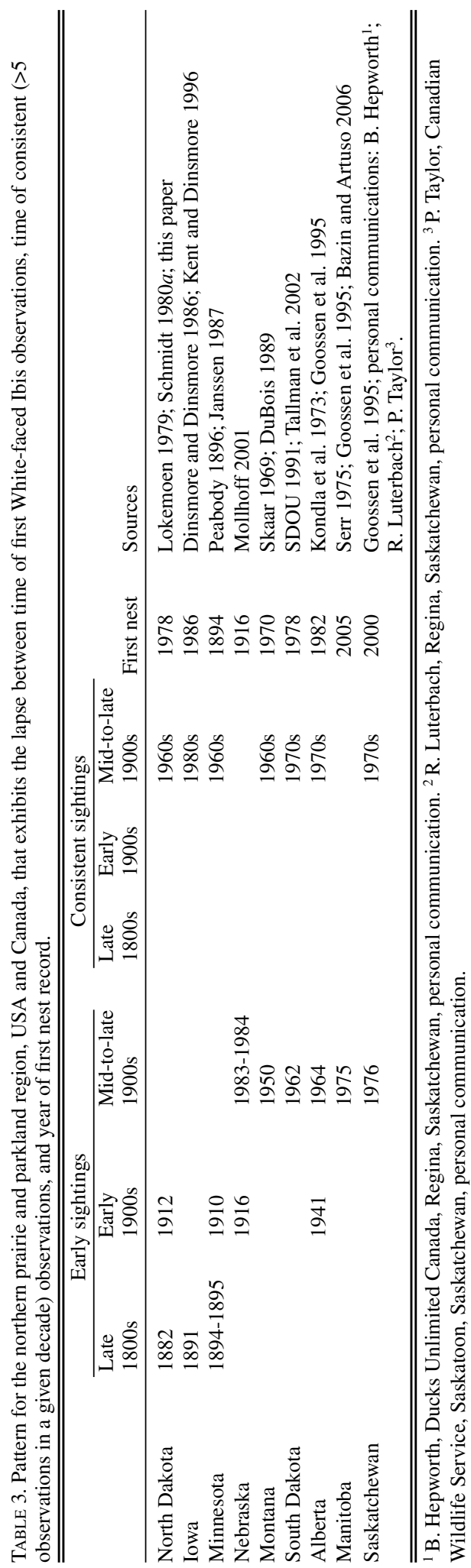


of temporarily flooded wetlands due to drainage, the number of permanent wetlands in the form of basin wetlands and riverine impoundments increased in the state (Lokemoen 1979).

Kantrud (1992) suggested that prairie wildfires and grazing by large ungulates, two major ecological forces during presettlement times, were responsible for the restricted distribution of Broadleaf Cattail prior to the invasion of Narrowleaf Cattail. Many semipermanent wetlands in eastern North Dakota, eastern South Dakota, and western Minnesota that were grazed and that were dominated by semi-open stands of Hardstem Bulrush (Schoenoplectus acutus) presently are not grazed and are dominated by dense stands of cattail. Gary Krapu (U.S. Geological Survey, Jamestown, North Dakota, personal communication) recalls that, prior to the mid-1950s in North Dakota, most wetlands experienced grazing pressure by livestock or were hayed. In the late 1950 s and 1960 s, however, many farmers began to focus exclusively on small-grain production, phasing out livestock production. Livestock were beneficial in stopping the growth of dense stands of cattails by eating young, green cattail shoots. With the loss of grazing pressure, Narrowleaf Cattail more easily became established in wetlands. The decline in farm operations that raised livestock was hastened by the Soil Bank Program in the 1950 s, which provided farmers with annual payments under 5-to-10 year contracts to idle their cropland by planting to perennial cover. This program indirectly also encouraged the idling of wetlands as farmers reduced the number of livestock that they produced.

During the 1950s and 1960s in southern portions of the species' breeding range, ibis breeding habitat was being lost due to human encroachment or drought. Breeding colonies of ibises disappeared or decreased in size due to habitat loss or pesticide contamination in Oregon, California, and Nevada (Ryder 1967; Ryder and Manry 1994). This decline coincided with increased sightings in Minnesota, North Dakota, South Dakota, and Montana (Table 3). It is plausible that this highly nomadic species sought and found better breeding conditions in the northern prairie and parkland region than in its more traditional breeding range.

Banding studies during the 1960s found that shooting was the major cause of reported deaths for this species, with many bands recovered from Mexico (DuBois 1989). The species was a gamebird until the early twentieth century, when international treaties conferred protection from hunting or harassment. Lokemoen (1979) postulated that ibis population increases might have been due in part to federal protection. Although federal protection of migratory birds began in 1918 with the signing of the Migratory Bird Treaty (Legal Information Institute $2005^{*}$ ), resources were not available for widespread federal enforcement in North Dakota until the 1940s (G. Krapu, personal communication).
After the late 1960s, pesticide contamination and continued habitat loss occurred in southern states, coinciding with more frequent ibis sightings and first nest records in several northern states. King et al. (1980) monitored eggshell thickness, pollutant residues, and the population status of the species in Texas from 1969 through 1976 . They found that nesting populations declined by $42 \%$, associated with low reproductive success caused by DDE-induced shell thinning and dieldrin mortality. Taylor et al. (1989) reported that the ibis population doubled in the late 1970s in Utah and also increased in Oregon. They attributed these increases to flooding in the Great Basin during the early 1980s, recovery from reduced productivity caused by DDT in the 1970 s, and/or natural fluctuations in ibis populations.

Other Ciconiiformes species also increased in occurrences and expanded their distribution during the same time period in North Dakota and other areas of the northern prairie and parkland region (Jones and Malcolm 1978; Lokemoen 1979; Schmidt 1979a,b, 1980b; Lambeth 1980). The first Cattle Egret in North Dakota was reported in 1971 (Lokemoen 1979), and the first nesting colony was discovered in 1976 among nests of Black-crowned Night-Herons and Little Blue Herons (Egretta caerulea) (Jones and Malcolm 1978). More Cattle Egret colonies were discovered in the ensuing years (Schmidt 1980b). It is possible that the presence of the colonies of Cattle Egret and other colonial-nesting birds provided the stimulus that prompted ibis to establish colonies.

More recently, the increase in White-faced Ibis observations in North Dakota has coincided with the wet conditions experienced in the northern prairie and parkland region from 1993 to the present (NCDC 2004*). The current wet cycle may be the wettest period during the past 130 years (Winter and Rosenberry 1998). These wet conditions may be contributing to suitable habitat conditions for the ibis. Johnson (1994) documented large-scale pioneering expansion of nesting distributions of several species of western North American birds over the last three decades. Although Johnson (1994) did invoke climatic warming as a possible explanation, he believed that it was neither the sole explanation nor even the primary cause. Rather, he hypothesized that many of the species were responding to a decades-long increase in summer rainfall in regions beyond their former ranges, based on regional climatic trends. Summer moisture, perhaps coupled with a higher mean temperature, encouraged avian range expansions. Detailed correlations of local climatic data with temperature and moisture requirements of individual species would be necessary to establish causality (Johnson 1994).

We believe that the combination of adequate rainfall and invasion of Narrowleaf Cattail in the 1940s in North Dakota, the rapid establishment of Narrowleaf Cattail and its hybridization with the Broadleaf Cat- 
tail during the ensuing decades, the general expansion of other ciconiiform species, the conversion from ranching to small-grain production, wetland loss and poor ibis reproduction in the southern portions of the ibis breeding range, growing ibis populations in the Intermountain West region, wet conditions suitable for colonial waterbird establishment, and climatic changes have contributed to the growth of ibis populations in North Dakota. We suspect that the above factors also may have played a role in population changes elsewhere in the northern prairie and parkland region. Ibises are considered rare, localized breeders in the northern prairie and parkland region (Beyersbergen et al. 2004) and, more specifically, are considered locally uncommon in North Dakota (this paper), rare to locally uncommon in South Dakota (Sabo 1992), and a rare summer resident in Canada (Goossen et al. 1995).

The future status of ibis within the northern prairie and parkland region likely will depend upon precipitation patterns. With continuing years of adequate rainfall, wetlands that harbored colonies should continue to provide suitable habitat. There are no indications that the spread of monotypic stands of cattail within wetlands will abate, which should only aid in the spread of ibis into new breeding areas. Already, breeding sites in North Dakota that once contained only a few birds and nests now contain larger groups of nesting birds. With an onset of a prolonged drought, the quality of nesting habitat could decline in some wetlands, but water levels in other wetlands that had been inundated to the degree that they no longer supported emergent vegetation would recede and again allow the growth of deep-marsh vegetation that could harbor new nesting colonies. Even in a prolonged drought, colonies could persist at managed wetlands, such as those maintained within certain NWRs. From these colonies, ibis could disperse when precipitation levels again rise at previously dry wetlands.

\section{Acknowledgments}

We thank the many individuals who have contributed records of White-faced Ibis in North Dakota. We thank Richard Crawford, Todd Grant, Dave Griffiths, Craig Hultburg, Lawrence Igl, Will Meeks, and Mike Norton for providing detailed information on unpublished sightings. Will Meeks of the U.S. Fish and Wildlife Service procured funding and equipment for Joel Brice's graduate field research, and Richard Crawford served as his graduate advisor. Kathy Klimkiewicz of the Bird Banding Laboratory provided information on ibis banding records. Special thanks to Gary Krapu for sharing his knowledge and experiences of North Dakota birdlife and to him and Lawrence Igl for prompting discussions on factors relating to ibis population increases. Thank you to Rachel Bush for conducting library searches. Early drafts of the manuscript were reviewed by Steve Dinsmore, Lawrence Igl, Douglas Johnson, Gary Krapu, and Terry Shaffer.
Documents Cited (marked * in text)

Knutsen, G. A. 2004. Colonial nesting waterbird distribution and abundance within Long Lake National Wildlife Refuge Complex. U.S. Fish and Wildlife Service, Moffit, North Dakota.

Legal Information Institute. 2005. Cornell University Law School Legal Information Institute home page: U.S. Code Title 16. http://www.law.cornell.edu/uscode/html/uscode 16/usc_sup_01_16_10_7_20_II.html.

NAS (National Audubon Society). 2007. National Audubon Society Christmas Bird Count home page. http://audubon2. org/birds/cbc/hr/table.html.

NCDC (National Climatic Data center). 2004. National Climatic Data Center home page: climate division, precipitation, temperature, and drought data. http://www.ncdc. noaa.gov/onlineprod/drought/xmgr.html.

Phelps, W. A., and W. Meeks. 2001. Waterbird nesting colonies at Lake Alice National Wildlife Refuge. Unpublished report. U.S. Fish and Wildlife Service, Devils Lake Wetland Management District, Devils Lake, North Dakota.

Sauer, J. R., J. E. Hines, and J. Fallon. 2005. The North American Breeding Bird Survey, Results and Analysis 1966 - 2004. Version 2005.2. USGS Patuxent Wildlife Research Center, Laurel, Maryland. http://www.mbr-pwrc. usgs.gov/bbs/bbs.html.

USFWS (U.S. Fish and Wildlife Service). 2001. Long Lake National Wildlife Refuge and Long Lake Wetland Management District annual narrative report, Calendar Year 2001. Moffit, North Dakota.

USFWS (U.S. Fish and Wildlife Service). 2002. Long Lake National Wildlife Refuge and Long Lake Wetland Management District annual narrative report, Calendar Year 2002. Moffit, North Dakota.

USGS (U.S. Geological Survey). 2007. USGS Patuxent Wildlife Research Center, Laurel, Maryland. Bird Banding Laboratory home page. http://www.pwrc.usgs.gov/bbl.

\section{Literature Cited}

Bazin, R., and C. Artuso. 2006. First documented breeding record of White-faced Ibis in Manitoba. Blue Jay 64: 64-68.

Berkey, G. 1988. The nesting season: northern Great Plains. American Birds 42: 1305-1307.

Beyersbergen, G. W., N. D. Niemuth, and M. R. Norton. 2004. Northern prairie and parkland waterbird conservation plan. Prairie Pothole Joint Venture, Denver, Colorado.

Brice, J. S. 2003. Distribution, abundance and habitat use of overwater colonial nesting waterbirds at Lake Alice National Wildlife Refuge. M.S. thesis. University of North Dakota, Grand Forks, North Dakota.

Dinsmore, J. J., T. H. Kent, D. Koenig, P. C. Petersen, and D. M. Roosa. 1984. Iowa birds. Iowa State University Press, Ames, Iowa.

Dinsmore, S., and J. J. Dinsmore. 1986. White-faced Ibis nesting in Dickinson County. Iowa Bird Life 56: 120-121.

DuBois, K. 1989. Arising, alighting ibis. Montana Outdoors 20(6): 30-33.

Flockhart, D. T. Tyler. 2001. Rare or unusual bird sightings for Beaverhill Lake, AB, 1996-2000. Blue Jay 59: 33-40. 
Goossen, J. P., D. M. Ealey, H. Judge, and D. C. Duncan. 1995. Distribution and breeding status of the White-faced Ibis, Plegadis chihi, in Canada. Canadian Field-Naturalist 109: 391-401.

Houston, C. S. 1974. Fall migration: northern Great Plains. American Birds 28: 67-70.

Houston, C. S., and M. I. Houston. 1974. Nesting season: northern Great Plains. American Birds 28: 916-918.

Janssen, R. B. 1987. Birds in Minnesota. University of Minnesota Press, Minneapolis, Minnesota.

Johnson, N. K. 1994. Pioneering and natural expansion of breeding distributions in western North American birds. Studies in Avian Biology 15: 27-44.

Jones, L. A., and J. M. Malcolm. 1978. First nesting record of Cattle Egret and Little Blue Heron in North Dakota. Prairie Naturalist 10: 122.

Jorgenson, J. G., and S. J. Dinsmore. 2005. An assessment of the status of White-faced Ibis (Plegadis chihi) in the Great Plains. North American Birds 59: 376-381.

Kantrud, H. A. 1992. History of cattails on the prairies: wildlife impacts. Pages 9-12 in Proceedings of the Cattail Management Symposium. Edited by G. M. Linz. North Dakota State University, Fargo, North Dakota.

Kazeck, M. E. 1956. North Dakota, a human and economic geography. North Dakota Institute for Regional Studies, North Dakota Agricultural College, Fargo, North Dakota.

Kent, T. H., and J. J. Dinsmore. 1996. Birds in Iowa. Published by the authors, Iowa City and Ames, Iowa.

King, K. A., D. L. Meeker, and D. M. Swineford. 1980. White-faced Ibis populations and pollutants in Texas, 19691976. Southwestern Naturalist 2: 225-240.

Kondla, N. G., H. W. Pinel, C. A. Wallis, and C. R. Wershler. 1973. Avifauna of the Drumheller area, Alberta. Canadian Field-Naturalist 87: 377-393.

Kushlan, J. A., M. J. Steinkamp, K. C. Parsons, J. Capp, M. Acosta Cruz, M. Coulter, I. Davidson, L. Dickson, N. Edelson, R. Elliot, R. M. Erwin, S. Hatch, S. Kress, R. Milko, S. Miller, K. Mills, R. Paul, R. Phillips, J. E. Saliva, B. Sydeman, J. Trapp, J. Wheeler, and K. Wohl. 2002. Waterbird conservation for the Americas: the North American waterbird conservation plan, Version 1. Waterbird Conservation for the Americas, Washington, D.C.

Lambeth, S. 1980. Green Heron nesting in North Dakota. Prairie Naturalist 12: 109.

Lokemoen, J. T. 1979. The status of herons, egrets, and ibises in North Dakota. Prairie Naturalist 11: 97-110.

Martin, R. 2001. Fall migration: northern Great Plains. North American Birds 55: 68-69.

Martin, R. 2002. Fall migration: northern Great Plains. North American Birds 56: 66-67.

Martin, R. 2004. Fall migration: northern Great Plains. North American Birds 58: 95-97.

Mollhoff, W. J. 2001. Nebraska breeding bird atlas. Nebraska Ornithologists' Union Occasional Papers Number 7. Nebraska Technical Series Number 20. Nebraska Game and Parks Commission, Lincoln, Nebraska.
Peabody, P. B. 1896. White-faced Ibis breeding in Minnesota. Auk 13: 79.

Robinson, E. B. 1966. History of North Dakota. University of Nebraska Press, Lincoln, Nebraska.

Ryder, R. A. 1967. Distribution, migration and mortality of the White-faced Ibis (Plegadis chihi) in North America. Bird Banding 38: 257-277.

Ryder, R. R., and D. E. Manry. 1994. White-faced Ibis. In The birds of North America, No. 130. Edited by A. Poole and F. Gill. The Academy of Natural Sciences, Philadelphia and the American Ornithologists' Union, Washington, D.C.

Sabo, T. 1992. Plegadis ibis - a change in status. Birder's Journal 1: 241-256.

chmidt, R. 1979a. Burleigh County, second nesting location of Cattle Egrets in North Dakota. Prairie Naturalist 11: 10 .

Schmidt, R. 1979b. First nesting record of a Louisiana Heron in North Dakota. Prairie Naturalist 11: 93-95.

Schmidt, R. A. 1980a. First breeding records of the Whitefaced Ibis in North Dakota. Prairie Naturalist 12: 21-23.

Schmidt, R. A. 1980b. Third nesting of Cattle Egret in North Dakota. Prairie Naturalist 12: 19-20.

Serr, E. M. 1975. Breeding season - northern Great Plains region. American Birds 29: 867-870.

Serr, E. M. 1978. Breeding season - northern Great Plains region. American Birds 32: 1176.Serr, E. M. 1979. Breeding season - northern Great Plains region. American Birds 33: 874-875.

Skaar, P. D. 1969. Birds of the Bozeman latilong. Published by the author. Bozeman, Montana.

South Dakota Ornithologists' Union. 1991. The birds of South Dakota. SDOU (South Dakota Ornithologists' Union), Aberdeen, South Dakota.

Stewart, R. E., and H. A. Kantrud. 1971. Classification of natural ponds and lakes in the glaciated prairie region. U.S. Fish and Wildlife Service, Resource Publication 92. Bureau of Sport Fisheries, Washington, D.C.

Svingen, D., and R. E. Martin. 2003. First report of the North Dakota Rare Bird Committee. Prairie Naturalist 35: 257-272.

Tallman, D. A., D. L. Swanson, and J. S. Palmer. 2002. Birds of South Dakota. Midstates/Quality Quick Print, Aberdeen, South Dakota.

Taylor, D. M., C. H. Trost, and B. Jamison. 1989. The biology of the White-faced Ibis in Idaho. Western Birds 20: 125-133.

USCB (U.S. Census Bureau). 2005. Decennial census. Washington, DC.

Winter, T. C., and D. O. Rosenberry. 1998. Hydrology of prairie pothole wetlands during drought and deluge: a 17year study of the Cottonwood Lake wetland complex in North Dakota in the perspective of longer term measured and proxy hydrological records. Climate Change 40: 189209.

Wood, N. A. 1923. A preliminary survey of the bird life of North Dakota. University of Michigan Museum of Zoology Miscellaneous Publications, Number 10. University of Michigan Press, Ann Arbor, Michigan.

Received 12 October 2006

Accepted 7 May 2007 